\title{
Polityka regionalna Unii Europejskiej: wnioski z doświadczeń Finlandii w latach 1995-1999
}

\section{Wstęp}

Od połowy XX w. jednym z największych wyzwań, z jakimi muszą zmierzać się władze Finlandii, jest niekorzystna sytuacja demograficzna północnej części tego państwa - Laponii ${ }^{1}$. Celem większości działań podejmowanych w tym regionie jest zahamowanie jego depopulacji. Działania te polegają na polepszeniu sytuacji ekonomicznej społeczeństwa dzięki nakładom na edukację, infrastrukturę i poprawę konkurencyjności regionu. Kiedy 1 I 1995 r. Finlandia, wraz ze Szwecją i Austrią, stała się członkiem Unii Europejskiej, Laponia, jako region Finlandii, została objęta programami (i działaniami instrumentów finansowych) Unii Europejskiej, z których część była przeznaczona dla obszarów o skrajnie małym zaludnieniu. W przypadku Finlandii głównym celem większość działań realizowanych w ramach polityki regionalnej w latach 1995-1999 było poprawienie sytuacji demograficznej obszarów peryferyjnych, szczególnie Laponii.

Celem artykułu jest próba analizy efektywności polityki regionalnej Unii Europejskiej i Finlandii wobec obszarów peryferyjnych w pierwszym dla tego państwa okresie programowania 1995-1999. Szczególna uwaga jest poświęcona Laponii. Ze względu na niekorzystne warunki przyrodnicze region ten borykał się z wieloma problemami, spośród których pierwotnym wydaje się być depopulacja. Podjęta zostanie próba odpowiedzi na pytanie o efekty polityki regionalnej Wspólnoty prowadzonej wobec obszarów peryferyjnych o skrajnie małym zaludnieniu.

\section{Polityka regionalna Unii Europejskiej}

Źródeł polityki regionalnej Unii Europejskiej można doszukiwać się w traktatach rzymskich, gdzie w preambule umawiające się państwa chcą utworzyć Europejską Wspólnotę Gospodarczą, troszcząc się o wzmocnienie jedności swoich systemów gospodarczych i zapewnienie ich harmonijnego rozwoju przez zmniejszenie różnic między poszczególnymi regionami oraz usuwanie opóźnienia mniej uprzywilejowanych regionów (Traktaty Rzymskie, 1957). Jednak pierwsze działania mające na celu

${ }^{1}$ Pojęcie Laponia nie jest jednoznaczne. Może ono określać region administracyjny w Finlandii, region kulturowy (obejmujący swoim zasięgiem tereny zamieszkałe przez Saamów prowadzących tradycyjny tryb życia) lub region geograficzny (obejmujący północne części Półwyspu Skandynawskiego i Półwyspu Kolskiego). 
rozwój regionalny zostały podjęte dopiero w latach 70. XX wieku (Klimowicz, 2014, s. 203). Polityka regionalna jest jedną z najważniejszych polityk Unii Europejskiej i ulega ciągłej ewolucji. Na gruncie przepisów traktatowych nie istnieje jednak jedna powszechnie przyjęta definicja polityki regionalnej. Nie istnieje również oficjalna definicja regionu (Szczudlińska-Kanoś, 2009, s. 35). Definicje regionu można stworzyć na podstawie kryteriów geograficznych, historycznych, gospodarczych, społeczno-kulturowych i polityczno-administracyjnych. Dla celów badań polityki regionalnej Unii Europejskiej można przyjąć gospodarcze kryterium określenia regionu będącego podmiotem działań wspólnotowych (Huczek, 2010, s. 375).

W literaturze ogólne pojęcie polityki regionalnej dotyczy dwóch różnych aspektów działalności. Jeden to polityka regionalna państwa, zróżnicowana przestrzennie w zależności od warunków panujących w poszczególnych regionach państwa (Solarz, 2009, s. 143). Drugim rodzajem działalności jest pobudzenie rozwoju regionu przy wykorzystaniu jego potencjału wewnętrznego (zasoby naturalne, struktura demograficzna, warunki przyrodnicze). Natomiast polityka regionalna Unii Europejskiej to działania instytucji wspólnotowych, mające na celu wyrównanie dysproporcji rozwojowych i regionalnych na terenie całej Wspólnoty (Solarz, 2009, s. 144). Polityka regionalna Unii Europejskiej jest również formą solidarności - bowiem wsparcie trafia do regionów najbardziej potrzebujących (Polityka regionalna). Jednak każdy region boryka się z innymi problemami. Różne jest również postrzeganie problemów regionalnych w poszczególnych państwach. W artykule Przeglad, zmiany, reformy-zmiany polityki regionalnej w Unii Europejskiej $i$ w Norwegii D. Yuill, M. Ferry i T. Gross przedstawili problemy regionów i ich różną percepcję w 15 państwach „starej Unii Europejskiej”, Polsce i Norwegii (Yuill, Ferry, Gross, 2008, s. 5-37):

- Austria - tradycyjne zróżnicowania regionalne na osi wschód-zachód są w zaniku. Problem jest ograniczony do wymiaru miasto-wieś, nieuzasadniającego interwencji regionalnych w dużej skali. Bieżące problemy polityki obejmują: wysoki poziom migracji codziennych, zmiany demograficzne i obszary górskie/wiejskie; liberalizacja rynku i rosnące nierówności społeczne; problemy graniczne;

- Belgia - Flandria ogólnie dobrze prosperuje, ale ma problemy związane ze starymi okręgami górniczymi i problemy aglomeracji/braku przestrzeni. Punkt nacisku przesunął się w czasie z zagadnień zatrudnienia na potencjał innowacyjny/Bezpośrednie Inwestycja Zagraniczne (BIZ). Walonia ma znaczące, ale malejące zróżnicowania wewnętrzne. Główny przedmiot troski to dawne okręgi przemysłowe i wiejskie, a także niski poziom wykształcenia;

- Dania - pomijając obszary peryferyjne (Grenlandia, Wyspy Owcze), standardowe zróżnicowania regionalne są bardzo ograniczone. Polityka dąży do maksymalizacji regionalnego wkładu we wzrost ogólnokrajowy; stosuje się także preferencyjne podejście do mniej zamożnych/słabiej rozwijających się obszarów peryferyjnych;

- Finlandia - główny problem dotyczy różnic między północą i wschodem a resztą kraju oraz między aglomeracjami a oddalonymi obszarami w głębi kraju. Główną troską polityki jest zmiana demograficzna, oddziaływająca najsilniej na słabo zaludnione obszary;

- Francja - dostrzega się coraz większą złożoność problemów. Główne problemy to struktura miejska, obszary wiejskie i relokacja firm. Politycy dążą do wzrostu 
ogólnej konkurencyjności i zarazem zajmują się sprawami zróżnicowań na poziomie subregionalnym;

- Grecja - w związku z peryferyjnym położeniem tego państwa i zróżnicowaną strukturą regionalną, zróżnicowania wewnętrzne na tle pozostałych państw UE są znaczne. Jednak zróżnicowania te nie pogłębiają się;

- Hiszpania - pod względem PKB północno-wschodnie regiony położone na północ od rzeki Ebro oraz Madryt i Baleary plasują się powyżej średniej. Podejście krajowe do polityki regionalnej jest silnie osadzone w funduszach strukturalnych, z naciskiem na sprawy konkurencyjności/produktywności; mamy też do czynienia z konstytucyjnym zobowiązaniem zrównoważonego rozwoju;

- Holandia - postrzeganie problemu jest niejednolite. Niektórzy uważają, że zróżnicowania są bardzo ograniczone, inni twierdzą, że północ jest nadal w gorszej sytuacji niż reszta kraju. Polityka koncentruje się przede wszystkim na rozwoju kraju, ale kładzie też nacisk na słabsze obszary na północy;

- Irlandia - w ciągu ostatniej dekady PKB per capita znacznie przekroczyło średnią unijną. Jednocześnie wyzwania związane $\mathrm{z}$ aglomeracjami i bardziej peryferyjnym południem i zachodem są poważne i skontrastowane. Zainteresowanie polityki tymi problemami wzrasta;

- Luksemburg - „problem” regionalny jest tradycyjnie wiązany z restrukturyzacją przemysłu stalowego (na południu) i wrażliwym rolnictwem (na północy). Polityka koncentruje się na kwestiach granicznych i promocji konkurencyjności międzynarodowej. Zajmuje się też podniesieniem poziomu dywersyfikacji gospodarczej;

- Niemcy - główny problem dotyczy utrzymującego się społeczno-ekonomicznego zróżnicowania między starymi i nowymi (powstałymi na obszarze byłej NRD) landami, co wpływa na ogólny wynik ekonomiczny. Według części polityków niemieckich polityka rozwoju ekonomicznego powinna koncentrować się na „regionach metropolitalnych". Jednak istnieją również opinie, według których polityka regionalna powinna koncentrować się na rozwoju obszarów wiejskich;

- Norwegia - główne wyzwania regionalne dotyczą słabego zaludnienia i trudno dostępnych obszarów peryferyjnych, a także koncentracji ludności w obszarach miejskich oraz problemów związanych ze strukturą przemysłu i zależnością od pierwszego sektora. Silny element działań na szczeblu powiatu został wprowadzony (przywrócony) przez Białą Księgę z 2006 roku w celu poprawy sytuacji obszarów wiejskich i peryferyjnych;

- Polska - rośnie dystans między dobrze rozwiniętymi regionami rdzeniowymi, położonymi głównie na zachodzie, a wiejskimi i peryferyjnymi położonymi głównie na wschodzie. Polityka dąży do rozwiązania podwójnego wyzwania, jakim jest dogonienie reszty Unii Europejskiej, przy jednoczesnym zmniejszeniu zróżnicowań regionalnych;

- Portugalia - nowe spojrzenie na problem regionalny zastąpiło tradycyjne podziały (północ-południe, wybrzeże-reszta kraju) nowymi, na które składają się przesunięcie w słabym rozwoju z wnętrza kraju do obszarów peryferyjnych, zróżnicowanie między regionami Porto i Lizbony. Polityka zmierza ku wzrostowi konkurencyjności regionalnej w celu maksymalizacji wzrostu i zmniejszenia zróżnicowań; 
- Szwecja - zróżnicowania rosną. Bardziej zurbanizowane obszary na południu są na etapie koncentracji ludności i aktywności ekonomicznej, podczas gdy północny wschód spodziewa się najwyższego udziału osób starszych w przyszłości. Trwają debaty na temat znaczenia większych i bardziej zróżnicowanych regionów dla maksymalizacji wzrostu ogólnokrajowego i dla bardziej zrównoważonego rozwoju regionalnego;

- Wielka Brytania - głównym problemem pozostaje dystans dzielący południowy wschód od reszty kraju. Rośnie ponadto świadomość coraz większych zróżnicowań subregionalnych. Regionalne agencje rozwoju starają się rozwiązywać te subregionalne wyzwania. Obszary miejskie są postrzegane jako główne czynniki wzrostu;

- Włochy - ekonomiczny i społeczny dualizm północ-południe nadal jest główną przyczyną interwencji polityki regionalnej. Słabe ogólne wyniki ekonomiczne prowadziły jednak do coraz ostrzejszych dyskusji na temat właściwych działań polityki (Yuill, Ferry, Gross, 2008, s. 10-11).

Na podstawie przytoczonego powyżej opracowania można zauważyć, że z podobnymi problemami regionalnymi borykają się państwa nordyckie: Finlandia, Szwecja i Norwegia. We wszystkich tych państwach występuje problem północnych obszarów peryferyjnych o skrajnie małym poziomie zaludnienia. W przypadku Polski i Niemiec zróżnicowany rozwój regionów wynika z zaszłości historycznych. W Polsce granica pomiędzy regionami bardziej a słabiej rozwiniętymi wciąż pokrywa się z granicami pomiędzy zaborami (Strategia, 2019, s. 50-53). Natomiast w Niemczech różnica ta jest skutkiem podziału tego państwa na Niemcy Wschodnie i Zachodnie (Raport). Na obszarze całej Unii Europejskiej istnieją różnice w rozwoju gospodarczym poszczególnych regionów. Mówi o tym koncepcja rozwoju przestrzennego Alberta Hirschmana zakładająca, że rozwój gospodarczy dokonuje się nierównomiernie i jest skoncentrowany w tzw. „geograficznych centrach wzrostu” (Grosse, 2002, s. 28). Każdy region ma jednocześnie własną charakterystykę i potrzeby, nie jest zatem możliwe zupełne wyrównanie rozwoju gospodarczego wszystkich regionów, a jedynie zmniejszenie dysproporcji.

Sporządzona 15 X 1985 r. w Strasburgu Europejska Karta Samorządu Lokalnego w preambule wskazuje na to, że społeczności lokalne i regionalne stanowią jedną z podstaw ustroju demokratycznego. Jednocześnie Europejska Karta Samorządu Lokalnego wyraża prawo społeczności regionalnych do zrzeszania się (Łazutka, 2012, s. 402).

\section{Euroregiony}

Dla niwelowania dysproporcji gospodarczo-społecznych w Europie i realizacji polityki spójności Unii Europejskiej szczególne znaczenie mają euroregiony (Greta, Lewandowski, 2008, s. 72). Współczesne euroregiony powstają zazwyczaj jako wynik procesów endogenicznych (Jastrzębska, 2008, s. 97). Jednocześnie samo pojęcie euroregionu nie jest jednoznaczne, a jego definicje są zależne od podmiotu i sposobu badań i analiz (Jastrzębska, 2008, s. 95-97). W nomenklaturze Unii Europejskiej euroregiony to stałe struktury współpracy transgranicznej między bezpośrednio sąsiadującymi ze sobą władzami jednostek lokalnych i regionalnych, usytuowanych wzdłuż wspólnych granic państwowych (Opinia, 2007). W rozumieniu prawnym Unii Europejskiej euroregiony charakteryzują się następującymi cechami: 
- euroregiony i podobne struktury nie są ani nową formą administracji, ani też nowym szczeblem rządowym, lecz stanowią platformę wymiany i transgranicznej współpracy horyzontalnej pomiędzy władzami lokalnymi i regionalnymi; tym samym wzmacniają współpracę na linii pionowej między władzami lokalnymi lub regionalnymi, rządami i instytucjami europejskimi;

- są to stowarzyszenia władz lokalnych i regionalnych znajdujących się po obu stronach granicy państwowej, czasami dysponujących zgromadzeniem parlamentarnym;

- są to stowarzyszenia transgraniczne, posiadające stały sekretariat, zespół techniczny i administracyjny oraz własne zasoby;

- w niektórych wypadkach są to podmioty podlegające prawu prywatnemu, oparte na organizacjach nienastawionych na zysk lub fundacjach działających po obu stronach granicy, zgodnie z właściwymi systemami prawa krajowego. Czasami są to podmioty podlegające prawu publicznemu, oparte na umowach międzypaństwowych i odpowiedzialne między innymi za zaangażowanie władz lokalnych i regionalnych oraz współpracę między nimi;

- euroregiony są często definiowane nie tylko poprzez swój zasięg geograficzny czy polityczno-administracyjny - przejawiają również wspólne cechy gospodarcze, społeczne lub kulturowe (Opinia, 2007).

Jednocześnie należy zaznaczyć, że euroregiony są tworzone przez partnerów z co najmniej dwóch państw (Misztal, 2017, s. 305). Część badaczy identyfikuje euroregion jako szczególną formę regionu transgranicznego (Warych-Juras, 2003, s. 178). Współpraca $\mathrm{w}$ ramach euroregionów wykracza poza tradycyjny podział krajów europejskich i stanowi istotny czynnik wpływający na integrację europejską.

\section{Polityka regionalna w Finlandii}

Przez lata fińska gospodarka opierała się na produkcji pierwotnej. Jednak powojenny rozwój gospodarczy Finlandii był na tyle szybki, że dysproporcje pomiędzy tym państwem a najbardziej rozwiniętymi gospodarkami Europy i świata znacznie się zmniejszyły. Szybki rozwój gospodarczy oraz zmiany strukturalne spowodowały efekt centralizacji zarówno działalności gospodarczej, jak i ludności. Nastąpiła migracja ludności do regionów centralnych i południowych, gdzie położony jest obszar metropolitalny Helsinek oraz większość miast i ośrodków miejskich Finlandii. Postęp technologiczny w rolnictwie i leśnictwie, najszybsza w Europie urbanizacja i industrializacja w latach 60. i 70. XX w., zmieniły obraz fińskiego społeczeństwa stwarzając nowe wyzwania dla kształtowania polityki regionalnej. Władze Finlandii podjęły działania mające na celu rozbudowę infrastruktury, decentralizację przemysłu wytwórczego i stworzenie państwa opiekuńczego. Jednak nie zapobiegły one gwałtownej depopulacji obszarów wiejskich w latach 60. i na początku 70. (Tervo, 2005, s. 267).

W latach 70. i 80. XX w. rozwój regionów Finlandii był dość wyrównany. Natomiast lata 90 . były okresem przemian gospodarczych i drastycznych zmian strukturalnych. W latach 1991-1993 państwo to zostało dotknięte poważną recesją, w wyniku której spadła zarówno produkcja, jak i zatrudnienie (Tervo, 2005, s. 267). 
Na skutek rozpadu Związku Radzieckiego i związanego z tym kryzysu gospodarczego na początku lat 90. XX wieku załamał się fiński handel z Rosją, z którego żyła niemal cała fińska gospodarka. W okresie negocjacji akcesyjnych Finlandia znajdowała się w największej, w swojej powojennej historii, recesji. O skali kryzysu, jaki dotknął fińską gospodarkę, świadczyć może fakt, że w latach 1990-1993 (okres najgłębszej recesji) odnotowano 13\% spadek PKB. Jeszcze bardziej dramatycznie przedstawiały się wskaźniki bezrobocia w tym okresie. Wzrosło ono z 3,5\% w roku 1990 do niemal 17\% w 1994 roku (IndexMundi, 2020). O pogarszającej się wówczas sytuacji ekonomicznej społeczeństwa fińskiego świadczą również następujące wskaźniki (dotyczące lat 1990-1993):

- inwestycje prywatne zmniejszyły się o $50 \%$;

- konsumpcja spadła o $10 \%$;

- wpływy z eksportu zmniejszyły się o $10 \%$;

- wartość spółek giełdowych spadła o 70\%;

- ceny nieruchomości obniżyły się o 50\%.

W tym samym okresie podwoiło się również realne zadłużenie Finów (Kiander, 2009, s. 6-12).

Sytuacja taka spowodowała wzrost niepokojów społecznych. W październiku 1991 roku Centralna Organizacja Fińskich Związków Zawodowych zorganizowała na Placu Senackim w Helsinkach manifestację w celu obrony miejsc pracy. Udział w niej wzięło około 40 tys. osób. Również w październiku 1991 roku środowiska zrzeszające emerytów, rencistów i osoby najuboższe zorganizowały przed siedzibą parlamentu manifestację przeciwko cięciom świadczeń socjalnych. Udział w niej wzięło 20000 osób (Männikkö, 2015, s. 11).

W listopadzie 1991 roku nastąpiła 14\% dewaluacja marki fińskiej (Brycz, Filar, 2013, s. 12). Jednocześnie wstrzymana została waloryzacja rent i emerytur. We wrześniu 1992 roku kurs fińskiej marki został uwolniony. Skutkowało to natychmiastową deprecjacją fińskiej waluty o 27\% (Honkapohja, Koskela, Leibfritz, Uusitalo, 2009, s. 43). Dało to spadek jej wartości o ponad 40\% w ciągu roku (XI 1991-X 1992). W latach 1991-1994 siła nabywcza przeciętnego wynagrodzenia w Finlandii spadła o niemal 20\% (Gorodnichenko, Mendoza, Tesar, 2012, s. 1600-1625).

Oparta na wiedzy, eksporcie technologii i inwestycjach w know-how fińska gospodarka zaczęła się ożywiać w drugiej połowie lat 90., a pod koniec XX w. stała się jedną z najszybciej rozwijających się i najbardziej konkurencyjnych gospodarek świata. Na przełomie wieków, jako państwo, Finlandia przeżywała rozkwit. Jednak po recesji z początku lat 90. rozwój gospodarczy tego państwa opierał się w znacznej większości na ośrodkach miejskich i uniwersyteckich. Obszary wiejskie, w tym północna część Finlandii - Laponia - ulegały dalszej depopulacji i marginalizacji (Tervo, 2005, s. 267).

\section{Polityka regionalna Unii Europejskiej wobec Finlandii w latach 1995-1999, ze szczególnym uwzględnieniem Laponii}

Finlandia, Szwecja i Austria stały się członkami Unii Europejskiej 1 I 1995 roku. W tym czasie celem nadrzędnym polityki Unii Europejskiej było niwelowanie różnic 
między najbiedniejszymi i najbogatszymi regionami oraz stworzenie wspólnej płaszczyzny do prowadzenia polityki strukturalnej. W jej ramach UE wyodrębniła sześć kategorii celów:

- cel 1. - wspieranie rozwoju i dostosowania strukturalnego regionów słabo rozwiniętych (zacofanych);

- cel 2. - restrukturyzacja regionów (regionów przygranicznych lub części regionów, które są dotknięte upadkiem przemysłu);

- cel 3. - zwalczanie bezrobocia długookresowego;

- cel 4. - ułatwianie integracji zawodowej młodzieży i przystosowanie pracowników do zmian w przemyśle;

- cel 5. - reforma wspólnej polityki rolnej; w jego ramach wyodrębniono dwa cele:

a) - przyśpieszenie modernizacji i dostosowanie struktur rolniczych $\mathrm{w}$ ramach

Unii Europejskiej,

b) - pomoc w rozwoju i zmianach strukturalnych obszarów wiejskich;

- cel 6. - ułatwienie rozwoju regionów o małej gęstości zaludnienia w krajach skandynawskich. Cel ten ustanowiono dopiero po przyłączeniu się do Unii Finlandii i Szwecji.

W zakres polityki regionalnej wchodziły cele $\mathrm{nr}$ 1., 2., 5b. oraz 6., natomiast pozostałe cele dotyczyły grup ludności bez względu na ich miejsce zamieszkania (Łodziński, 1998, s. 2-15).

W Finlandii realizowano cele: 2., 3., 4., 5a., 5b. i 6. W latach 1995-1999 łączna kwota przeznaczona dla tego państwa z funduszy strukturalnych wyniosła 1502000 euro.

Dofinansowanie dla Finlandii na realizację celów określonych na lata 1995-1999 w mln euro

\begin{tabular}{|l|c|c|c|c|c|c||}
\hline \multicolumn{1}{|c|}{ Cel } & $\mathbf{2}$ & $\mathbf{3} \mathbf{i} \mathbf{4}$ & $\mathbf{5 a}$ & $\mathbf{5 b}$ & $\mathbf{6}$ & Suma \\
\hline $\begin{array}{l}\text { Lączne dofinansowanie z funduszy } \\
\text { strukturalnych UE }\end{array}$ & 179 & 336 & 347 & 190 & 450 & 1502 \\
\hline
\end{tabular}

Źródło: Clement, 2000, s. 83.

W latach 1999-1995 na realizację polityki regionalnej (cele 2, 5a i 6) w całej Finlandii przeznaczono $819 \mathrm{mln}$ euro. W tej kwocie ponad połowa środków była przeznaczona na realizację celu 6 .

Kwota 179 mln euro, przeznaczona na realizację celu 2., obejmowała osiem obszarów Finlandii: Finlandię Południowo-Zachodnią, Satakuntę, Południową Karelię, Kokkolę, Päijät-Häme, Wschodnią Uusimę, Kymenlaakso i Środkową Finlandię (Bachtler, Taylor, 1999, s. 13). Obszary te spełniały następujące kryteria przyznania środków na realizację celu 2.

- stopa bezrobocia powyżej średniej unijnej;

- odsetek zatrudnionych w przemyśle nie mniejszy od średniej unijnej;

- spadkowy trend zatrudnienia w przemyśle (Williams, 1996, s. 123).

Obszary objęte działaniami w ramach realizacji celu 5b. musiały spełniać główne kryterium, którym był niski poziom rozwoju społeczno-gospodarczego (oceniany na podstawie PKB per capita) oraz co najmniej dwa z trzech następujących wskaźników: 
- wysoki odsetek zatrudnionych w rolnictwie;

- niski poziom dochodów rolniczych;

- mała gęstości zaludnienia i (lub) malejąca liczba mieszkańców (Komisja Europejska, 2015).

Cel 6. dotyczył regionów na poziomie NUTS $2^{2}$ o niskiej gęstości zaludnienia (8 lub mniej osób na km²) (Łodziński, 1998, s. 2-15). Ze względu na kryteria wsparcia w ramach polityki strukturalnej Unii Europejskiej, granice pomiędzy regionami na poziomach NUTS 2 i NUTS 3 ulegały w Finlandii częstym zmianom. Działania takie były spowodowane przede wszystkim kwalifikowaniem obszarów do realizacji programów w ramach celu 6. (Gidlund, Jerneck, 2000, s. 166-168).

Cel 6. był realizowany w całej północnej i większości wschodniej Finlandii. Obszary te stanowiły $60 \%$ terytorium kraju i były zamieszkane przez $16,6 \%$ jego populacji. Problemem, jaki należało rozwiązać, była zmniejszająca się liczba mieszkańców najbardziej peryferyjnych obszarów Finlandii. Ponieważ liczba miejsc pracy w rolnictwie i usługach publicznych malała, należało podjąć działania w celu dywersyfikacji możliwości zatrudnienia. Priorytetowo traktowane były sektory mające tendencje wzrostowe, takie jak leśnictwo i turystyka, oraz inwestycje w ochronę środowiska, energetykę, technologie arktyczne i telekomunikację. Jednak największa część środków finansowych została przeznaczona na zahamowanie spadku dochodów z rolnictwa oraz przeprowadzenie zmian strukturalnych w tym sektorze. Największą pod względem powierzchni częścią obszaru objętego działaniami w ramach celu 6. była Laponia. Przy opracowywaniu programów dla tego regionu brano pod uwagę jego cechy charakterystyczne:

- przyśpieszający spadek liczby ludności, spowodowany emigracją ludzi młodych oraz ujemnym przyrostem naturalnym;

- odsetek osób w wieku emerytalnym większy niż przeciętny w Finlandii;

- poziom wykształcenia niższy od przeciętnego;

- stały spadek liczby miejsc pracy w rolnictwie i leśnictwie;

- stopa bezrobocia wyższa niż przeciętna;

- permanentny trend spadkowy liczby miejsc pracy w tradycyjnym przemyśle przetwórczym (od początku lat 70.);

- największym pracodawcą był sektor publiczny, zwłaszcza samorządy;

- mała przedsiębiorczość mieszkańców regionu (pomimo znacznych dotacji na rozwój prywatnej przedsiębiorczości w latach 70. i 80. ogólna liczba miejsc pracy malała);

- brak dużych ośrodków miejskich i znaczne odległości pomiędzy skupiskami ludności;

- znaczne odległości od potencjalnych rynków zbytu dla produktów lokalnych;

- obszary pierwotnej przyrody, dające możliwości rozwoju turystyki (jednak turystyka masowa nie mogła być rozwijana ze względu na dużą wrażliwość północnych ekosystemów; rozwój turystyki powinien być oparty na zasadach zrównoważonego rozwoju);

- duży udział Laponii w krajowej produkcji energii;

${ }^{2}$ NUTS - Klasyfikacja Jednostek Terytorialnych do Celów Statystycznych. Standard geograficzny służący do statystycznego podziału państw członkowskich Unii Europejskiej na trzy poziomy regionalne o określonej liczbie mieszkańców. 
- populacja Saamów, dla których podstawowym źródłem utrzymania była hodowla reniferów (Katajamäki, 2002, s. 26).

Programy mające realizować cel 6 . w Laponii były oparte na trzech priorytetach:

- priorytet 1. - rozwój przedsiębiorczości i wzrost konkurencyjności lokalnych firm;

- priorytet 2. - rozwój zasobów ludzkich i wzrost poziomu wiedzy w społeczeństwie;

- priorytet 3. - rozwój rolnictwa, leśnictwa i rybołówstwa oraz rozwój obszarów wiejskich i poziomu ochrony środowiska (Katajamäki, 2002, s. 27).

W Finlandii w realizację celu 6. zaangażowanych było osiem ministerstw. Środkami pochodzącymi z Europejskiego Funduszu Orientacji i Gwarancji Rolnej oraz z Finansowego Instrumentu Orientacji Rybołówstwa zarządzało jedynie Ministerstwo Rolnictwa i Leśnictwa. Najbardziej skomplikowana sytuacja miała miejsce w przypadku zarządzania środkami pochodzącymi z Europejskiego Funduszu Rozwoju Regionalnego.

Rys. 1. Struktura administrowania funduszami przeznaczonymi na realizację celu 6. w Finlandii

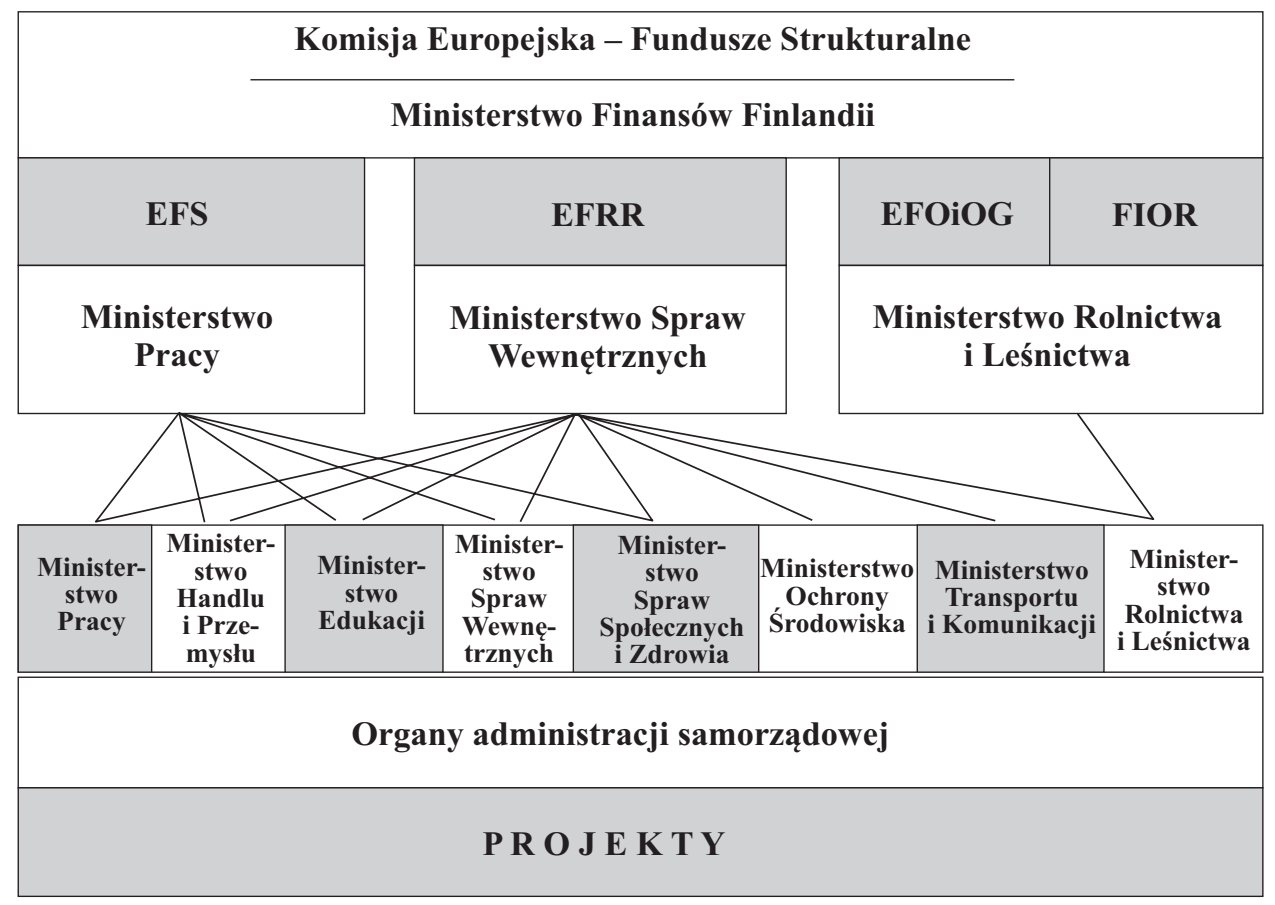

Źródło: Katajamäki, 2002, s. 31.

Słabość systemu zarządzania środkami Unii Europejskiej w Finlandii polegała na braku współpracy pomiędzy poszczególnymi ministerstwami. Często zdarzało się, że administracja na szczeblu regionalnym otrzymywała sprzeczne i wykluczające się instrukcje od poszczególnych ministerstw (Katajamäki, 2002, s. 36).

Działania w ramach realizacji celu 6 . nie przyniosły w Finlandii zakładanych efektów. Przy ogólnokrajowym wzroście populacji liczba mieszkańców obszarów mało zaludnionych wciąż spadała. 
Rys. 2. Zmiana zaludnienia obszarów objętych działaniami celu 6

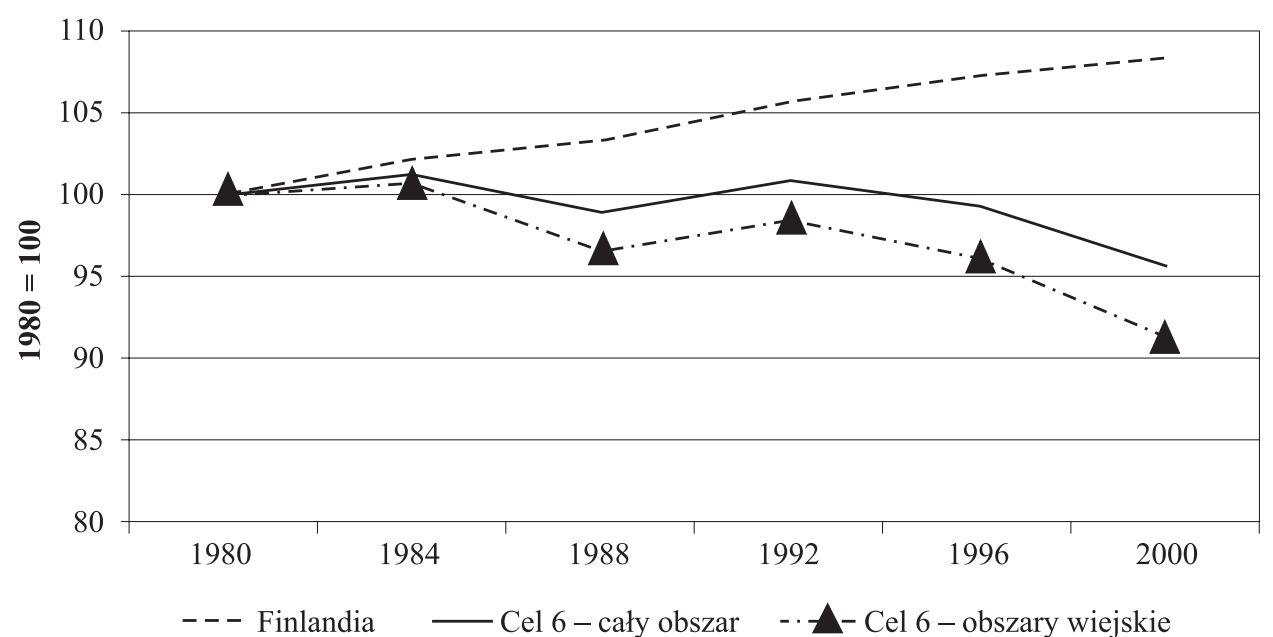

Źródło: Katajamäki, 2002, s. 42.

Spadek ludności dotyczył zwłaszcza Laponii - jedynie w 1999 roku liczba mieszkańców tego regionu zmniejszyła się o 1,3\% (Tilastokeskus, 2021). Przyczyny depopulacji obszarów peryferyjnych Finlandii tkwią przede wszystkim w zmniejszaniu się zatrudnienia w rolnictwie i leśnictwie oraz zwiększających się dysproporcjach w jakości życia pomiędzy tymi obszarami a ośrodkami miejskimi.

Wzrost gospodarczy, jakiego doświadczyła Finlandia w latach 1995-1999, spowodował spadek bezrobocia w całym państwie, jednak na obszarach objętych działaniami w ramach celu 6 . był on wolniejszy niż w pozostałych regionach kraju.

\section{Rys. 3. Porównanie tempa spadku bezrobocia na terenach celu 6. i całej Finlandii}

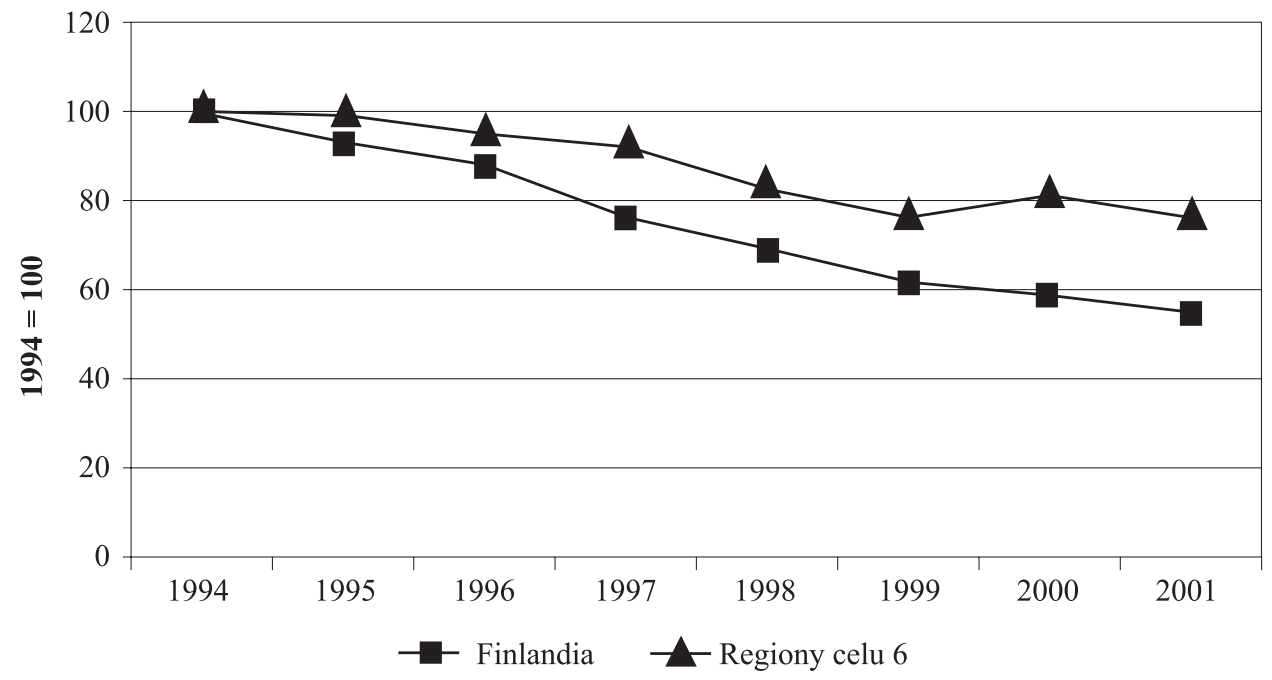

Źródło: Katajamäki, 2002, s. 45. 
W Finlandii problemy z realizacją założeń celu 6. wynikały z długoletnich tradycji centralnego zarządzania państwem i sektorowego charakteru administracji. Wszystkie istotne decyzje były podejmowane na szczeblu ministerialnym i nie były konsultowane ze społecznościami lokalnymi. Dotyczyło to również zatwierdzania projektów w ramach celu 6 . Potrzeby społeczności lokalnych były rozpoznawane przede wszystkim na podstawie danych statystycznych. Charakterystyka peryferyjnych obszarów Finlandii, w tym Laponii, nie była w pełni znana władzom w Helsinkach (Katajamäki, 2002, s. 50).

\section{Podsumowanie}

Polityka regionalna prowadzona w Laponii w latach 1995-1999 nie przyniosła spodziewanych efektów z powodu niekorzystnych czynników, których korelacja nie została w pełni przeanalizowana. Czynniki te miały charakter kumulatywny:

- niska gęstość zaludnienia, skrajnie duże odległości i surowy klimat;

- duże koszty utrzymania miejsc pracy w izolowanych i niewielkich skupiskach ludności oraz niższy poziom edukacji;

- wysoki udział w zatrudnieniu sektora publicznego (opieka nad osobami starszymi, opieka zdrowotna, edukacja i utrzymanie infrastruktury) (Declaration, s. 1-4).

Błędy popełnione przy planowaniu polityki regionalnej wobec Laponii w pierwszym dla Finlandii okresie programowania zostały zauważone zarówno przez rząd tego państwa, jak i przez Komisję Europejską. Wydaje się, że zakładane efekty projektów realizowanych z funduszy strukturalnych Unii Europejskiej w Laponii w latach 1995-1995 miały jedynie charakter życzeniowy.

W kolejnych okresach Finlandia zmieniła swoją politykę regionalną. Zmiany te miały zwiększyć efektywność wykorzystania środków finansowych przeznaczonych na rozwój Laponii. Jednak pomimo realizacji w Laponii wielu koncepcji politycznych, mających na celu zahamowanie wyludniania się tego regionu, proces ten nadal trwa (Nilsen, 2021).

\section{Bibliografia}

Bachtler J., Taylor S. (1999), Objective 2: experiences, lessons and policy implications, Final Report, University of Strathclyde, Glasgow.

Brycz M., Filar D. (2013), Nordycki Kryzys Bankowy 1990-1993 i globalny kryzys finansowy 2007$2011-z$ perspektywy aktualnej sytuacji nordyckich banków, „Bezpieczny Bank”, nr 2-3 (51-52).

Clement K. (2000), Economic Development and Environmental Gain. European Environmental Integration and Regional Competitives, Earthscan Publications Ltd, London.

Declaration on the future European Cohesion Policy presented by the extremely sparsely populated areas of Finland and Sweden, Declaration on the future European Cohesion Policy presented by the extremely sparsely populated areas of Finland and Sweden (europa.eu), 10.05.2021.

Gidlund J., Jerneck M. (2000), Local and Regional Governance in Europe: Evidence from Nordic Regions, Edward Elgar Pub, Cheltenham.

Gorodnichenko Y., Mendoza E. G., Tesar L. L. (2012), The Finnish Great Depression: From Russia with Love, „American Economic Review”, nr 102(4). 
Greta M., Lewandowski K. (2008), Euroregion jako instrument realizacji spójności społeczno-ekonomicznej i Strategii Lizbońskiej, „Nierówności społeczne a wzrost gospodarczy”, nr 12.

Grosse T. G. (2002), Przeglad koncepcji teoretycznych rozwoju regionalnego, „Studia Regionalne i Lokalne", $\mathrm{nr} 8$.

Honkapohja S., Koskela E. A., Leibfritz W., Uusitalo R. (2009), Economic Prosperity Recaptured. The Finnish Path from Crisis to Rapid Growth, MIT Press, Cambridge.

Huczek A. (2010), Polityka regionalna jako instrument rozwoju spoleczno-gospodarczego polskich regionów, „Nierówności społeczne a wzrost gospodarczy”, nr 16.

IndexMundi (2020), Finland Unemployment rate, Finland Unemployment rate - Economy (indexmundi.com), 9.05.2021.

Jastrzębska W. (2008), Rola euroregionów $i$ wspótpracy transgranicznej w procesie integracji europejskiej, w: Spójność społeczno-ekonomiczna a modernizacja regionów transgranicznych, red. M. G. Woźniak, Wydawnictwo Uniwersytetu Rzeszowskiego, Rzeszów.

Katajamäki H. (2002), Ex-post evaluationof objective 6 programmes in Finland and Sweden for the period 1995-99. Synthesis Report, University of Vaasa,Vaasa.

Kiander J. (2009), The great depression of Finland 1990-1993: causes and consequences, https://www. europarl.europa.eu/document/activities/cont/200912/20091216ATT66587/20091216ATT66587EN.pdf, 9.05.2021.

Klimowicz M. (2014), Ewolucja celów polityki regionalnej Unii Europejskiej w procesie integracji gospodarczej, w: Procesy integracyjne $i$ dezintegracyjne w Europie, red. A. Pacześniak, M. Klimowicz, OTO, Wrocław.

Komisja Europejska (2015), Rural areas, Regional Policy Inforegio (europa.eu), 10.05.2021.

Krajowa Strategia Rozwoju Regionalnego 2030 (2019), Ministerstwo Funduszy i Polityki Regionalnej, Warszawa.

Łazutka P. (2012), Specyfika euroregionów polsko-niemieckiego pogranicza w porównaniu do euroregionów na wschodniej granicy Polski, w: Formy współdziałania jednostek samorzadu terytorialnego, red. B. Dolnicki, Wolters Kluwer Polska sp. z o.o., Warszawa.

Łodziński S. (1998), Polityka regionalna w Unii Europejskiej - Fundusze Strukturalne i Fundusz Spójności, Kancelaria Sejmu. Biuro Studiów i Ekspertyz. Wydział Analiz Ekonomicznych i Społecznych, Warszawa.

Männikkö H. (2015), Eläkeläiset kampanjoivat „,oikeudenmukaisten leikkausten” puolesta, „Kansanääni”, nr 5/15.

Misztal A. (2017), Rola euroregionów w rozwoju inicjatyw klastrowych, „Zeszyty Naukowe Politechniki Śląskiej”, nr kol. 1972.

Nilsen T. (2021), Lapland sees a population decline that will continue for years to come, "The Barents Observer", Lapland sees a population decline that will continue for years to come | The Independent Barents Observer (thebarentsobserver.com), 16.05.2021.

Opinia Europejskiego Komitetu Ekonomiczno-Społecznego w sprawie euroregionów, Dziennik Urzędowy UE 2007/C 256/131, EUR-Lex - 52007IE1002 - EN - EUR-Lex (europa.eu), 9.05.2021.

Polityka regionalna, Regional policy, Unia Europejska (europa.eu), 9.05.2021.

Raport o stanie jedności Niemiec. „Różnice nie do przezwyciężenia” (2018), DW, Raport o stanie jedności Niemiec. „Różnice nie do przezwyciężenia”, Niemcy - bieżąca polityka niemiecka. Wiadomości DW po polsku, DW, 26.09.2018, 9.05.2021.

Solarz P. (2009), Rozwój regionalny i polityka regionalna w Polsce w okresie 2004-2009, w: Polska pięć lat w Unii Europejskiej, red. S. Konopacki, Łódź.

Szczudlińska-Kanoś A. (2009), Kobiety na regionalnej scenie politycznej, w: Kobiety wobec polityki - kobiety w polityce. Historia, realia, perspektywy, red. A. Frątczak, Krakowska Akademia im. Andrzeja Frycza Modrzewskiego, Kraków. 
Tervo H. (2005), Regional Policy Lessons from Finland, w: Regional Disparities in Small Countries. Advances in Spatial Science, red. D. Felsenstein, B. A. Portnov, Springer, Berlin.

Tilastokeskus (2021), Tunnuslukuja väestöstä alueittain, 1990-2020, Tunnuslukuja väestöstä muuttujina Alue, Tiedot ja Vuosi. PxWeb (stat.fi), 10.05.2021.

Traktaty Rzymskie (1957), Traktat_rzymski (praca.gov.pl), 9.05.2021.

Warych-Juras A. (2003), Euroregiony jako nowa forma wspótpracy europejskiej, w: Badania i podróże naukowe krakowskich geografów, t. 1, red. Z. Górka, J. Więcław-Michniewska, Polskie Towarzystwo Geograficzne. Oddział w Krakowie, Kraków.

Williams R. H. (1996), European Union Spatial Policy and Planning, Paul Chapman Pub, London.

Yuill D., Ferry M., Gross T. (2008), Przeglą, zmiany, reformy - zmiany polityki regionalnej w Unii Europejskiej i w Norwegii, ,Studia Regionalne i Lokalne”, nr 31.

\section{Streszczenie}

W artykule podjęto próbę analizy efektywności polityki regionalnej Unii Europejskiej i Finlandii wobec obszarów peryferyjnych w pierwszym dla tego państwa okresie programowania 1995-1999. Szczególna uwaga została poświęcona Laponii. Ze względu na niekorzystne warunki przyrodnicze region ten borykał się z wieloma problemami, spośród których pierwotnym wydaje się być depopulacja.

Polityka regionalna prowadzona wobec Laponii miała na celu zahamowanie tego procesu. Jednak błędy popełnione przy planowaniu skutkowały jej niepowodzeniem. Można zatem postawić hipotezę, że nie wysokość nakładów finansowych przeznaczonych na zwiększenie konkurencyjności regionu, ale znajomość jego specyfiki może przynieść pożądane efekty. Tymczasem, w kontekście polityki regionalnej wobec Laponii, okres 1995-1999 charakteryzował się niewłaściwym planowaniem opartym na zbyt powierzchownych analizach.

Słowa kluczowe: polityka regionalna, Unia Europejska, Finlandia, Laponia

\section{European Union Regional Policy: lessons learned from Finland's experience in 1995-1999}

\section{Summary}

The article attempts to analyze the effectiveness of the regional policy of the European Union and Finland towards peripheral areas in the first programming period for this country, 1995-1999. Particular attention was devoted to Lapland. Due to unfavorable natural conditions, the region struggled with many problems, the primary of which seems to be depopulation. Lapland's regional policy aimed to stop this process. However, mistakes made in its planning resulted in its failure. Therefore, it can be hypothesized that it is not the amount of financial outlays intended to increase the competitiveness of the region, but the knowledge of its specificity, that may bring the desired results. Meanwhile, in the context of regional policy towards Lapland, the period 1995-1999 was characterized by inadequate planning based on overly superficial analyzes.

Key words: regional policy, European Union, Finland, Lapland 
